\title{
Optimisation of beef tenderisation treated with bromelain using response surface methodology (RSM)
}

\author{
S. Zainal, K. Z. Nadzirah", A. Noriham, I. Normah
}

Department of Food Science and Technology, Faculty of Applied Sciences, Universiti Teknologi MARA, Shah Alam, Selangor, Malaysia; ${ }^{*}$ Corresponding Author: zira_scorpio@yahoo.com

Received 2013

\section{ABSTRACT}

The purpose of this study is to determine the optimum condition for the tenderization of beef by bromelain using Response Surface Methodology (RSM). Initially, bromelain powder was produced from pineapple crown of variety N36. Production of the bromelain powder involves several process steps such as extraction, purification, desalting and freeze drying. The cube size beef of round part was treated with bromelain at different pHs of beef, immersion temperatures, bromelain solution concentrations, and immersion times according to the experimental design which was recommended by RSM of MINITAB software version 15. Beef tenderness was then measured by Texture Analyser. The MINITAB software Version 15 was used to optimise the tenderisation of beef by bromelain. The determination coefficient $\mathrm{R}^{2}$ was $99.97 \%$ meaning that the experimental data were acceptable. It was found that beef could be optimize tenderised $89.907 \%$ at the optimum condition at $\mathrm{pH}$ of beef of 5.4 , immersion temperature of $60^{\circ} \mathrm{C}$, bromelain solution concentration of $0.1682 \%$ and immersion time of 10 minutes. The verification value of beef tenderisation at the feasible optimum condition which was determined by experiment was $\mathbf{8 9 . 5 7 1 \%}$. Since the difference between the verification and predicted values was less than $5 \%$, therefore, the optimum condition for the tenderisation of beef predicted by MINITAB software Version 15 could be accepted.

Keywords: Beef; Bromelain; Tenderisation; Response Surface Methodology (RSM)

\section{INTRODUCTION}

Beef from Brahman breed is known for its toughness
[1]. Thus, it is unsatisfactory to the consumer, if the meat is so tough that it is difficult to eat [2]. Therefore, numerous attempts have been made to encounter this problem and tenderising beef using bromelain becomes one of the widely used methods to improve the beef tenderness. This is because bromelain showed hydrolytic activity on the connective tissue leading to the better tenderisation of the tough meat [3].

Bromelain is a proteolytic enzyme found in pineapple plant [4-5] where it is accumulated in the entire part with different extents and properties depending on its source [6]. Production of bromelain powder involves extraction, purification, desalting and drying processes which can be performed using varieties of procedure. In the present study, production of the bromelain powder from pineapple crown of variety $\mathrm{N} 36$ was carried out according to the method by [7] with slight modification.

The action of bromelain in tenderising beef is affected by $\mathrm{pHs}$ of beef [8-9] immersion temperatures, bromelain solution concentrations and immersion times [10,11]. Research on the optimisation of beef tenderisation treated with bromelain has not been carried. Therefore, this study was conducted to determine the optimum condition for the tenderisation of beef by bromelain using Response Surface Methodology (RSM).

RSM is a collection of statistical techniques for designing experiments, building models, evaluating the effects of factors on the response and searching for the optimum conditions [12]. The principal advantage of using RSM is the number of experimental runs required to evaluate multiple factors and their interactions can be reduced [13-16]. Consequently, less time-consuming used to optimise a process compared to other approaches [17].

\section{MATERIALS AND METHODS}

\subsection{Materials}

Pineapple crown of variety N36 from maturity index 2 was obtained from Peninsula Plantations Sdn Bhd at 
Simpang Renggam, Johor, Malaysia. Beef of round part from three years old bull of Brahman breed was purchased from a butcher at Kota Kemuning, Shah Alam, Selangor, Malaysia. Analytical grade of methanol and acetonitrile and food grade of acetic acid, sodium hydroxide, hydrochloric acid and sodium chloride were purchased from Merck Sdn Bhd (Petaling Jaya, Selangor, Malaysia). All other chemicals of analytical grade including standard bromelain were purchased from Sigma Technologies Sdn Bhd (Petaling Jaya, Selangor, Malaysia). Custom-made cation exchange resin and diafiltrator were purchased from IT Tech Research (M) Sdn Bhd (Subang Jaya, Malaysia) and Isetake Enterprise (Kajang, Selangor, Malaysia), respectively.

\subsection{Methods}

\subsubsection{Production of Bromelain Powder}

The pineapple crowns were extracted by crushing their small pieces using fruit juice processor with ratio of pineapple crown to purified water $1: 1$. The extract was filtered through a muslin cloth. Then, the pineapple crown extract was centrifuged at $360 \mathrm{xg}$ for $10 \mathrm{~min}$ at $4^{\circ} \mathrm{C}$. The clear supernatant was collected followed by purification process by Preparative High Performance Liquid Chromatography (HPLC) using cation exchange resin column of $21.2 \mathrm{~mm}$ internal diameter and $250 \mathrm{~mm}$ length. The eluents used were acetate buffer $(25 \mathrm{~mm}, \mathrm{pH} 4.0)$ and $1 \mathrm{M}$ sodium chloride $(\mathrm{NaCl})$ solution. Removal of salt in the purified bromelain samples was carried out by continuous diafiltrator with hollow fiber membrane using purified water for exchange. Finally, the desalted bromelain solution sample was converted to powder form using freeze dryer (Christ alpha 1-4LD Plus model).

\subsubsection{Optimisation of Beef Tenderisation Treated with Bromelain Using RSM}

\subsubsection{Tenderisation of Beef Using Bromelain}

Beef of round part was cut into cube size of approximately $2 \mathrm{~cm}^{3}$. Then, the beef cube was treated with bromelain at different $\mathrm{pHs}$ of beef, immersion temperatures, bromelain solution concentrations, and immersion times according to the experimental design which was recommended by RSM of MINITAB software Version 15 as shown in Table 2. Non-immersed or untreated beef cube was served as a control.

\subsubsection{Texture measurement}

Beef tenderness was measured by Texture Analyser TAX-T2i (Stable Micro Systems, Ltd., England, UK) using P2N needle probe with a load cell of $10 \mathrm{~kg}$ cross head speed equipped with a 0.5 in diameter. The depth of beef was $5 \mathrm{~mm}$.

\subsubsection{Optimisation using RSM of MINITAB Software Version 15}

The range of four selected factors namely $\mathrm{pH}$ of beef, immersion temperature, bromelain solution concentration and immersion time is as shown in Table 1.

The factors listed in Table 1 were then applied into MINITAB software Version 15 whereby full factorial Central Composite Design (CCD) is employed to obtain the experimental design as shown in Table 2.

Table 1. Coded and uncoded factors for the design of experiment.

\begin{tabular}{cccccc}
\hline & $\mathbf{- 2 . 0 0 0 ( - \boldsymbol { \alpha } )}$ & $\mathbf{- 1}$ & $\mathbf{0}$ & $\mathbf{1}$ & $\mathbf{2 . 0 0 0 ( \alpha )}$ \\
\hline $\mathrm{X}_{1}$ & 5.0 & 5.2 & 5.4 & 5.6 & 5.8 \\
$\mathrm{X}_{2}$ & 55 & 60 & 65 & 70 & 75 \\
$\mathrm{X}_{3}$ & 0.10 & 0.15 & 0.20 & 0.25 & 0.30 \\
$\mathrm{X}_{4}$ & 5 & 10 & 15 & 20 & 25 \\
\hline
\end{tabular}

Where: $\mathrm{X}_{1}=\mathrm{pH}$ of beef, $\mathrm{X}_{2}=$ immersion temperature $\left({ }^{\circ} \mathrm{C}\right), \mathrm{X}_{3}=$ bromelain solution concentration $(\mathrm{w} / \mathrm{v} \%), \mathrm{X}_{4}=$ immersion time $(\mathrm{min})$.

Table 2. Experimental design recommended by MINITAB software Version 15.

\begin{tabular}{|c|c|c|c|c|}
\hline No & $X_{1}$ & $\mathbf{X}_{2}$ & $\mathbf{X}_{3}$ & $\mathbf{X}_{4}$ \\
\hline 1 & 5.2 & 60 & 0.15 & 10 \\
\hline 2 & 5.6 & 60 & 0.15 & 10 \\
\hline 3 & 5.2 & 70 & 0.15 & 10 \\
\hline 4 & 5.6 & 70 & 0.15 & 10 \\
\hline 5 & 5.2 & 60 & 0.25 & 10 \\
\hline 6 & 5.6 & 60 & 0.25 & 10 \\
\hline 7 & 5.2 & 70 & 0.25 & 10 \\
\hline 8 & 5.6 & 70 & 0.25 & 10 \\
\hline 9 & 5.2 & 60 & 0.15 & 20 \\
\hline 10 & 5.6 & 60 & 0.15 & 20 \\
\hline 11 & 5.2 & 70 & 0.15 & 20 \\
\hline 12 & 5.6 & 70 & 0.15 & 20 \\
\hline 13 & 5.2 & 60 & 0.25 & 20 \\
\hline 14 & 5.6 & 60 & 0.25 & 20 \\
\hline 15 & 5.2 & 70 & 0.25 & 20 \\
\hline 16 & 5.6 & 70 & 0.25 & 20 \\
\hline 17 & 5.0 & 65 & 0.20 & 15 \\
\hline 18 & 5.8 & 65 & 0.20 & 15 \\
\hline 19 & 5.4 & 55 & 0.20 & 15 \\
\hline 20 & 5.4 & 75 & 0.20 & 15 \\
\hline 21 & 5.4 & 65 & 0.10 & 15 \\
\hline 22 & 5.4 & 65 & 0.30 & 15 \\
\hline 23 & 5.4 & 65 & 0.20 & 5 \\
\hline 24 & 5.4 & 65 & 0.20 & 25 \\
\hline 25 & 5.4 & 65 & 0.20 & 15 \\
\hline 26 & 5.4 & 65 & 0.20 & 15 \\
\hline 27 & 5.4 & 65 & 0.20 & 15 \\
\hline 28 & 5.4 & 65 & 0.20 & 15 \\
\hline 29 & 5.4 & 65 & 0.20 & 15 \\
\hline 30 & 5.4 & 65 & 0.20 & 15 \\
\hline 31 & 5.4 & 65 & 0.20 & 15 \\
\hline
\end{tabular}

Where: $\mathrm{X}_{1}=\mathrm{pH}$ of beef, $\mathrm{X}_{2}=$ immersion temperature $\left({ }^{\circ} \mathrm{C}\right), \mathrm{X}_{3}=$ bromelain solution concentration $(\mathrm{w} / \mathrm{v} \%), \mathrm{X}_{4}=$ immersion time $(\mathrm{min})$. 
Response surface regression analysis was performed to obtain a second-order polynomial equation or model. Statistical analysis of the model was represented in the form of Analysis of Variance (ANOVA). The MINITAB software Version 15 was also used to generate response contour and surface plots.

\section{RESULTS AND DISCUSSION}

Results in Table 3 show that the highest actual and predicted responses were $89.907 \%$ and $89.813 \%$, respectively at factors whereby $\mathrm{pH}$ of beef was 5.6 , immersion temperature at $60^{\circ} \mathrm{C}$, bromelain solution concentration of $0.15 \%$ and immersion time of 10 minutes. The lowest actual and predicted responses were $58.267 \%$ and $58.608 \%$, respectively at factors whereby $\mathrm{pH}$ of beef was 5.4 , immersion temperature at $65^{\circ} \mathrm{C}$, bromelain solution concentration of $0.20 \%$ and immersion time of $15 \mathrm{~min}$ utes.

Table 3. Factors and comparison between actual (Y) and predicted (FITS) responses.

\begin{tabular}{|c|c|c|c|c|c|c|}
\hline \multirow{2}{*}{ No } & \multicolumn{4}{|c|}{ Test variables } & \multicolumn{2}{|c|}{ Responses } \\
\hline & $\mathbf{X}_{1}$ & $\mathbf{X}_{2}$ & $\mathbf{X}_{3}$ & $\mathbf{X}_{4}$ & Y (\%) & FITS (\%) \\
\hline 1 & 5.2 & 60 & 0.15 & 10 & 81.530 & 81.663 \\
\hline 2 & 5.6 & 60 & 0.15 & 10 & 89.907 & 89.813 \\
\hline 3 & 5.2 & 70 & 0.15 & 10 & 86.442 & 86.429 \\
\hline 4 & 5.6 & 70 & 0.15 & 10 & 87.551 & 87.543 \\
\hline 5 & 5.2 & 60 & 0.25 & 10 & 85.521 & 85.314 \\
\hline 6 & 5.6 & 60 & 0.25 & 10 & 86.931 & 86.971 \\
\hline 7 & 5.2 & 70 & 0.25 & 10 & 71.343 & 71.352 \\
\hline 8 & 5.6 & 70 & 0.25 & 10 & 66.053 & 65.974 \\
\hline 9 & 5.2 & 60 & 0.15 & 20 & 85.458 & 85.263 \\
\hline 10 & 5.6 & 60 & 0.15 & 20 & 89.147 & 89.439 \\
\hline 11 & 5.2 & 70 & 0.15 & 20 & 85.807 & 86.068 \\
\hline 12 & 5.6 & 70 & 0.15 & 20 & 83.273 & 83.208 \\
\hline 13 & 5.2 & 60 & 0.25 & 20 & 86.146 & 86.455 \\
\hline 14 & 5.6 & 60 & 0.25 & 20 & 84.399 & 84.139 \\
\hline 15 & 5.2 & 70 & 0.25 & 20 & 68.713 & 68.534 \\
\hline 16 & 5.6 & 70 & 0.25 & 20 & 59.013 & 59.181 \\
\hline 17 & 5.0 & 65 & 0.20 & 15 & 64.929 & 64.810 \\
\hline 18 & 5.8 & 65 & 0.20 & 15 & 64.205 & 64.209 \\
\hline 19 & 5.4 & 55 & 0.20 & 15 & 73.532 & 73.513 \\
\hline 20 & 5.4 & 75 & 0.20 & 15 & 63.511 & 63.417 \\
\hline 21 & 5.4 & 65 & 0.10 & 15 & 62.901 & 62.589 \\
\hline 22 & 5.4 & 65 & 0.30 & 15 & 52.202 & 52.401 \\
\hline 23 & 5.4 & 65 & 0.20 & 5 & 67.019 & 67.237 \\
\hline 24 & 5.4 & 65 & 0.20 & 25 & 65.972 & 65.640 \\
\hline 25 & 5.4 & 65 & 0.20 & 15 & 58.663 & 58.608 \\
\hline 26 & 5.4 & 65 & 0.20 & 15 & 58.574 & 58.608 \\
\hline 27 & 5.4 & 65 & 0.20 & 15 & 58.309 & 58.608 \\
\hline 28 & 5.4 & 65 & 0.20 & 15 & 58.267 & 58.608 \\
\hline 29 & 5.4 & 65 & 0.20 & 15 & 58.881 & 58.608 \\
\hline 30 & 5.4 & 65 & 0.20 & 15 & 58.894 & 58.608 \\
\hline 31 & 5.4 & 65 & 0.20 & 15 & 58.328 & 58.608 \\
\hline
\end{tabular}

Where: $\mathrm{X}_{1}=\mathrm{pH}$ of beef, $\mathrm{X}_{2}=$ immersion temperature $\left({ }^{\circ} \mathrm{C}\right), \mathrm{X}_{3}=$ bromelain solution concentration $(\mathrm{w} / \mathrm{v} \%), \mathrm{X}_{4}=$ immersion time $(\mathrm{min})$.

Table 4. Estimated regression coefficients of second-order polynomial model for optimisation of beef tenderisation treated with bromelain.

\begin{tabular}{ccccc}
\hline Term & Coefficient & SE Coefficient & $\mathbf{t}$ & $\mathbf{p}$ \\
\hline Constant & 5013.43 & 122.781 & 40.832 & 0.000 \\
$\mathrm{X}_{1}$ & -1433.30 & 47.267 & -30.324 & 0.000 \\
$\mathrm{X}_{2}$ & -38.43 & 0.984 & -39.051 & 0.000 \\
$\mathrm{X}_{3}$ & 2206.78 & 50.616 & 43.599 & 0.000 \\
$\mathrm{X}_{4}$ & -1.13 & 0.473 & -2.380 & 0.030 \\
$\mathrm{X}_{1} \mathrm{X}_{1}$ & 147.55 & 4.353 & 33.895 & 0.000 \\
$\mathrm{X}_{2} \mathrm{X}_{2}$ & 0.39 & 0.007 & 56.609 & 0.000 \\
$\mathrm{X}_{3} \mathrm{X}_{3}$ & -445.22 & 69.648 & -6.392 & 0.000 \\
$\mathrm{X}_{4} \mathrm{X}_{4}$ & 0.31 & 0.007 & 44.973 & 0.000 \\
$\mathrm{X}_{1} \mathrm{X}_{2}$ & -1.76 & 0.070 & -25.083 & 0.000 \\
$\mathrm{X}_{1} \mathrm{X}_{3}$ & -162.31 & 7.012 & -23.146 & 0.000 \\
$\mathrm{X}_{1} \mathrm{X}_{4}$ & -0.99 & 0.070 & -14.168 & 0.000 \\
$\mathrm{X}_{2} \mathrm{X}_{3}$ & -18.73 & 0.280 & -66.762 & 0.000 \\
$\mathrm{X}_{2} \mathrm{X}_{4}$ & -0.04 & 0.003 & -14.119 & 0.000 \\
$\mathrm{X}_{3} \mathrm{X}_{4}$ & -2.46 & 0.280 & -8.764 & 0.000 \\
$\mathrm{R}_{2}^{2}=99.97 \%$ & $\mathrm{R} 2(\mathrm{adj})$ & $99.95 \%$ & & \\
\hline
\end{tabular}

Where: $\mathrm{X}_{1}=\mathrm{pH}$ of beef, $\mathrm{X}_{2}=$ immersion temperature $\left({ }^{\circ} \mathrm{C}\right), \mathrm{X}_{3}=$ bromelain solution concentration $(\mathrm{w} / \mathrm{v} \%), \mathrm{X}_{4}=$ immersion time $(\mathrm{min}), \mathrm{SE}=$ standard error, $\mathrm{t}=$ student test, $\mathrm{p}=$ probability, $\mathrm{R}^{2}=\mathrm{R}-$ squared, $\mathrm{R}^{2}(\operatorname{adj})=$ adjusted $\mathrm{R}$ - squared.

Response surface regression analysis was performed and results of estimated regression coefficients of second-order polynomial model for optimisation of beef tenderisation treated with bromelain are as shown in Table 4.

Based on Table 4, the second-order polynomial model equation for optimisation of beef tenderisation treated with bromelain is as given in equation 2 :

$$
\begin{aligned}
\mathrm{Y}= & 5013.43-1433.30 \mathrm{X}_{1}-38.43 \mathrm{X}_{2}+2206.78 \mathrm{X}_{3} \\
& -1.13 \mathrm{X}_{4}+147.55 \mathrm{X}_{1}^{2}+0.39 \mathrm{X}_{2}^{2}-445.22 \mathrm{X}_{3}^{2} \\
& +0.31 \mathrm{X}_{4}^{2}-1.76 \mathrm{X}_{1} \mathrm{X}_{2}-162.31 \mathrm{X}_{1} \mathrm{X}_{3} \\
& -0.99 \mathrm{X}_{1} \mathrm{X}_{4}-18.73 \mathrm{X}_{2} \mathrm{X}_{3}-0.04 \mathrm{X}_{2} \mathrm{X}_{4} \\
& -2.46 \mathrm{X}_{3} \mathrm{X}_{4}
\end{aligned}
$$

Where: $X_{1}=p H$ of beef, $X_{2}=$ immersion temperature $\left({ }^{\circ} \mathrm{C}\right), \mathrm{X}_{3}=$ bromelain solution concentration $(\mathrm{w} / \mathrm{v} \%), \mathrm{X}_{4}$ $=$ immersion time $(\mathrm{min})$

The significant second-order polynomial model equation at the $5 \%$ level for the optimisation of beef tenderisation treated with bromelain is same as in equation (1). By referring to Table 4, it was found that linear factors such as $\mathrm{pH}$ of beef $\left(\mathrm{X}_{1}\right)$, immersion temperature $\left(\mathrm{X}_{2}\right)$ and immersion time $\left(\mathrm{X}_{4}\right)$ showed negative coefficients, respectively while bromelain solution concentration $\left(\mathrm{X}_{3}\right)$ 
showed positive coefficient. Square factors such as $\mathrm{pH}$ of beef $\left(X_{1} X_{1}\right)$, immersion temperature $\left(X_{2} X_{2}\right)$ and immersion time $\left(\mathrm{X}_{4} \mathrm{X}_{4}\right)$ showed positive coefficients, respectively while bromelain solution concentration $\left(\mathrm{X}_{3} \mathrm{X}_{3}\right)$ showed negative coefficient. Quadratic or interaction factors such as $\mathrm{pH}$ of beef and bromelain solution concentration $\left(\mathrm{X}_{1} \mathrm{X}_{3}\right), \mathrm{pH}$ of beef and immersion time $\left(\mathrm{X}_{1} \mathrm{X}_{4}\right)$, immersion temperature and bromelain solution concentration $\left(\mathrm{X}_{2} \mathrm{X}_{3}\right)$, immersion temperature and immersion time $\left(\mathrm{X}_{2} \mathrm{X}_{4}\right)$ and bromelain solution concentration and immersion time $\left(\mathrm{X}_{3} \mathrm{X}_{4}\right)$ showed negative coefficients, respectively.

Student $t$ and $p$ tests were performed and it was found that linear effect factors namely $\mathrm{X}_{1}, \mathrm{X}_{2}$ and $\mathrm{X}_{4}$ showed negative $t$ values, respectively while $X_{3}$ showed positive $t$ value. $p$ value for $X_{1}, X_{2}, X_{3}$ and $X_{4}$ were 0.000 , respectively. Square effect factors namely $\mathrm{X}_{1} \mathrm{X}_{1}, \mathrm{X}_{2} \mathrm{X}_{2}$ and $\mathrm{X}_{4} \mathrm{X}_{4}$ showed positive $t$ values, respectively while $\mathrm{X}_{3} \mathrm{X}_{3}$ showed negative $t$ value. $p$ value for $X_{1} X_{1}, X_{2} X_{2}, X_{3} X_{3}$ and $\mathrm{X}_{4} \mathrm{X}_{4}$ were 0.000 , respectively. Quadratic or interaction effect factors namely $\mathrm{X}_{1} \mathrm{X}_{3}, \mathrm{X}_{1} \mathrm{X}_{4}, \mathrm{X}_{2} \mathrm{X}_{3}, \mathrm{X}_{2} \mathrm{X}_{4}$ and $X_{3} X_{4}$ showed negative $t$ values, respectively and the respective $\mathrm{p}$ values were 0.000 . It means that all linear, square and quadratic or interaction factors gave significant $(\mathrm{p} \leq 0.05)$ effect on beef tenderisation.

Student $t$ test was used to determine the significance of the estimated coefficient of the regression model equation (equation 1). The student $t$ test value can be obtained by dividing each coefficient by its SE [18]. $p$ values were used as a tool to evaluate the significance and contribution of each factor and the statistical polynomial model equation [19]. [20,21] reported that the larger the magnitude of the $t$ value and the smaller the $p$ value, the more significant is the corresponding coefficient. Based on those reported by $[20,21]$, results of the present study showed that linear factors $\left(\mathrm{X}_{1}, \mathrm{X}_{2}, \mathrm{X}_{3}, \mathrm{X}_{4}\right)$, square factors $\left(\mathrm{X}_{1}^{2}\right.$, $\left.\mathrm{X}_{2}^{2}, \mathrm{X}_{3}^{2}, \mathrm{X}_{4}^{2}\right)$ and quadratic or interaction factors $\left(\mathrm{X}_{1} \mathrm{X}_{2}\right.$, $\mathrm{X}_{1} \mathrm{X}_{3}, \mathrm{X}_{1} \mathrm{X}_{4}, \mathrm{X}_{2} \mathrm{X}_{3}, \mathrm{X}_{2} \mathrm{X}_{4}, \mathrm{X}_{3} \mathrm{X}_{4}$ ) terms were highly significant.

The goodness of fit of the regression model was determined by determination coefficient $\mathrm{R}^{2}$ which provides a measure of how much variability in the observed response values can be explained by the experimental factors and their interactions [22]. Results in Table 4 showed that $\mathrm{R}^{2}$ value was $99.97 \%$ which signified $99.97 \%$ of variability in the observed response values could be explained by the model while only $0.03 \%$ of variability in the observed response values cannot be explained by the model. The remaining $\mathrm{R}^{2}$ value of $0.03 \%$ of the total variations would be due to other factors which were not included in the model.

The adjusted $\mathrm{R}^{2}$ was a corrected value for $\mathrm{R}^{2}$ after the elimination of unnecessary model terms. The adjusted $R^{2}$ would be remarkably smaller than the $\mathrm{R}^{2}$ if there were many non-significant terms have been included in the model [23]. In this study, it was found that the adjusted $\mathrm{R}^{2}$ was high and very close to the $\mathrm{R}^{2}$ and the respective values of adjusted $R^{2}$ and $R^{2}$ were $99.95 \%$ and $99.97 \%$. The high adjusted $R^{2}$ value was attributed to the absence of non-significant terms in the model. The high adjusted $\mathrm{R}^{2}$ and $\mathrm{R}^{2}$ values thus, indicated a high dependence and correlation between the observed and predicted value responses. This is based on [24], who also found the high adjusted $R^{2}$ (98.81) and $R^{2}$ (97.96) values in their study on the optimisation of enzymatic detection of cadmium in aqueous solution using immobilized urease from vegetable waste.

ANOVA was performed to test for the significance and adequacy of the second-order polynomial model [25]. The results are as summarised in Table 5.

The significance of regression was evaluated by $f$ and $p$ values using Fischer's and null-hypothesis tests. The $f$ value predicts the quality of the entire model considering all design factors at a time. The $\mathrm{p}$ value is the probability of the factors having very little or insignificant effect on the response. Larger $f$ value signifies better fit of the RSM model to the experimental data [26]. [27] stated that $f$ value with low $p$ value indicates the high significance of the regression model. However, the $p$ value should be lower than 0.05 for the model to be statistically significant [28]. Based on those reported by [26-28], the regression model found in this study was highly significant as denoted by the large $f$ and low $p$ values with 4185.84 and 0.000 , respectively. The linear, square and quadratic factors were also highly significant as denoted by the large $f$ values of $1073.06,10142.46$ and 1016.48 , respectively and low $p$ values of 0.000 , respectively.

Lack of fit test was also performed. It describes the variation in the data around the fitted model [29]. [28] testified that insignificant lack of fit indicates a good model. Insignificant lack of fit is desired as significant lack of fit indicates that there might be contributions in the regresses-response relationship that are not accounted for by the model. The $f$ value for the lack of fit can be

Table 5. ANOVA for optimisation of beef tenderisation treated with bromelain.

\begin{tabular}{lcccccc}
\hline \multicolumn{1}{c}{ Source } & DF & Seq SS & Adj SS & Adj MS & f & P \\
\hline Regression & 14 & 4610.77 & 4610.77 & 329.341 & 4185.84 & 0.000 \\
Linear & 4 & 938.89 & 337.71 & 84.428 & 1073.06 & 0.000 \\
Square & 4 & 3192.02 & 3192.02 & 798.005 & 10142.46 & 0.000 \\
Interaction & 6 & 479.86 & 479.86 & 79.976 & 1016.48 & 0.000 \\
Residual Error & 16 & 1.26 & 1.26 & 0.079 & & \\
Lack of fit & 10 & 0.83 & 0.83 & 0.083 & 1.16 & 0.445 \\
Pure Error & 6 & 0.43 & 0.43 & 0.071 & & \\
Total & 30 & 4612.03 & & & & \\
\hline
\end{tabular}

Where: DF = degree of freedom, Seq SS = sequential sum of square, Adj SS = adjusted sum of square, Adj $\mathrm{MS}=$ adjusted mean square, $\mathrm{f}=$ fischer, $\mathrm{p}=$ probability. 
obtained by dividing the lack of fit mean square by its pure error mean square. Results of the lack of fit are shown in Table 5 and it was found that the $f$ and $p$ values for the lack of fit were 1.16 and 0.445 , respectively. The insignificant $\mathrm{p}$ value thus indicates that the model was good and fitted well to the experimental data.

Response optimiser was performed and the results at optimum condition for target, maximum and minimum goals are shown in Figures 1, 2 and 3, respectively.

The feasibility of experiment for target, maximum and minimum goals was determined from the overlaid contour plot and the results are shown in Figures 4, 5 and 6, respectively.

Results of optimum conditions for different goals of actual and predicted responses and the feasibility of experiments obtained from response optimiser of MINITAB software Version 15 are shown in Table 6.

Based on Table 6, it was found that optimum conditions of target goal with $\mathrm{pH}$ of beef of 5.6, immersion temperature of $60^{\circ} \mathrm{C}$, bromelain solution concentration of $0.1864 \%$ and immersion time of 10 minutes, and maximum goal with $\mathrm{pH}$ of beef of 5.6, immersion temperature of 60 ${ }^{\circ} \mathrm{C}$, bromelain solution concentration of $0.1682 \%$ and

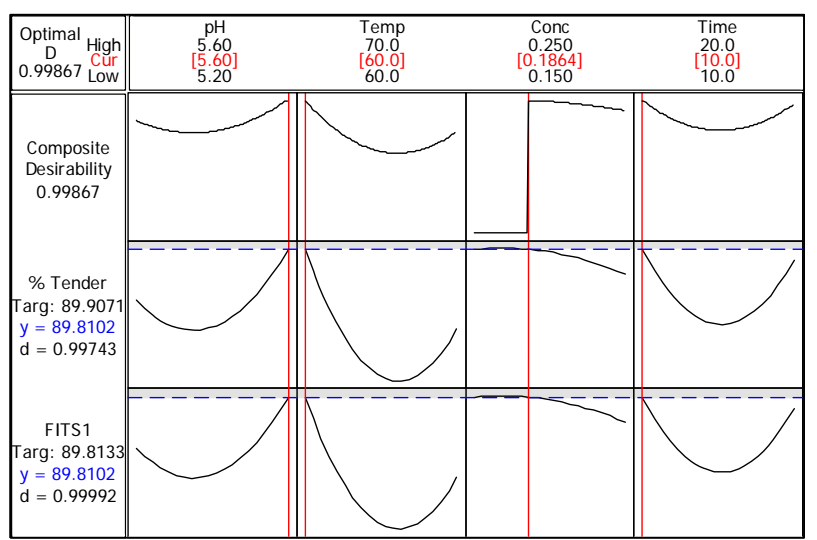

Figure 1. Response optimiser at optimum condition for target goal.

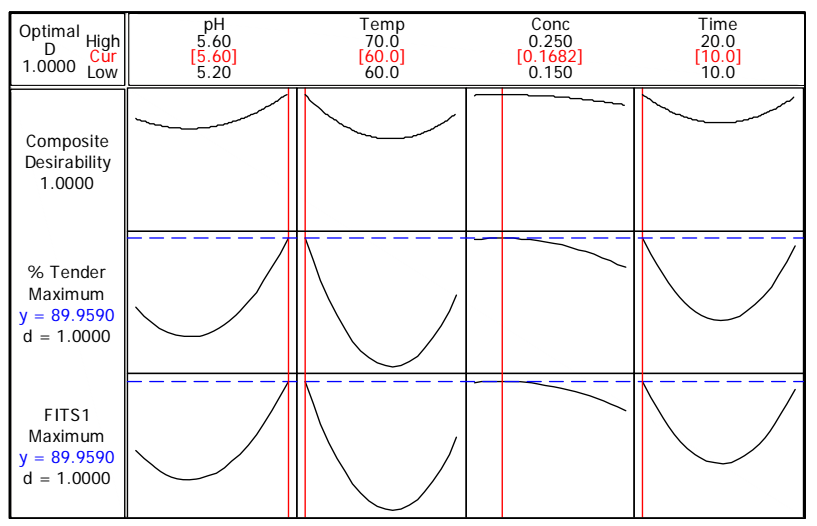

Figure 2. Response optimiser at optimum condition for maximum goal.

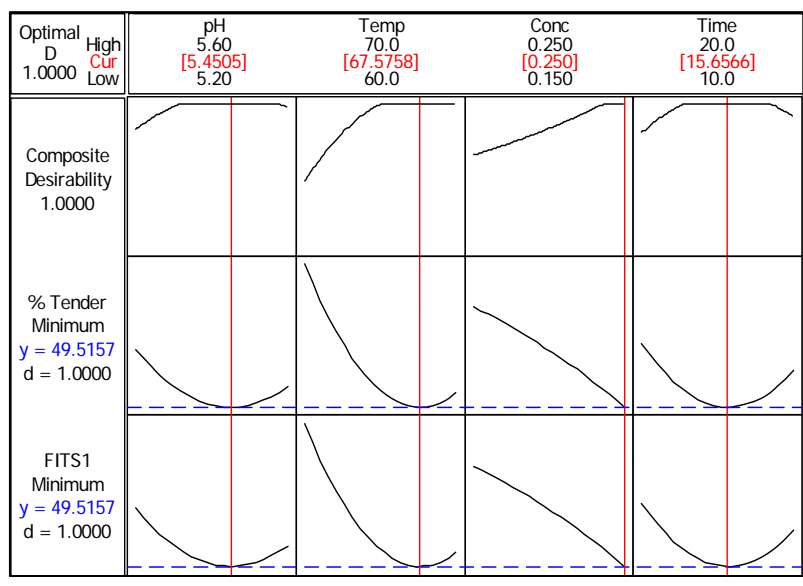

Figure 3. Response optimiser at optimum condition for minimum goal.

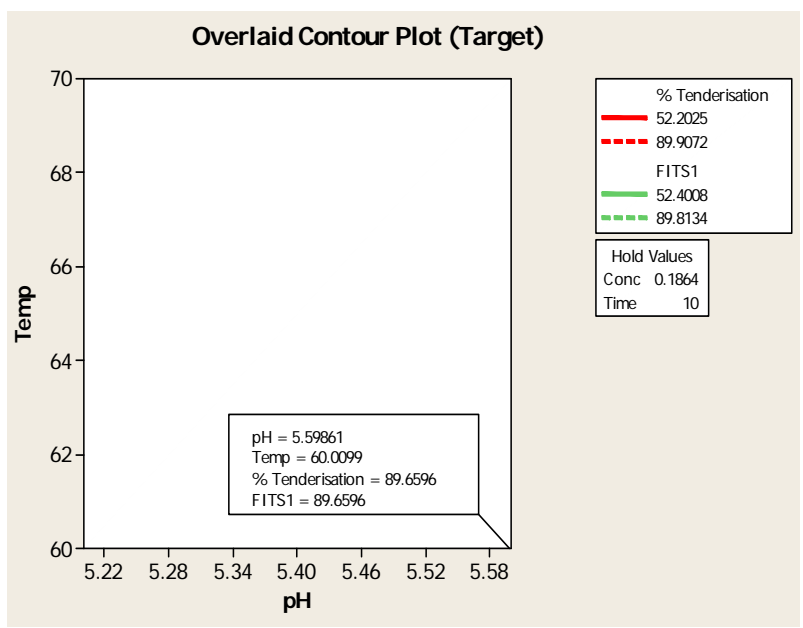

Figure 4. Overlaid contour plot at optimum condition for target goal; $\mathrm{pH}$ of beef of 5.6, immersion temperature of $60^{\circ} \mathrm{C}$, bromelain solution concentration of $0.1864 \%$ and immersion time of 10 minutes.

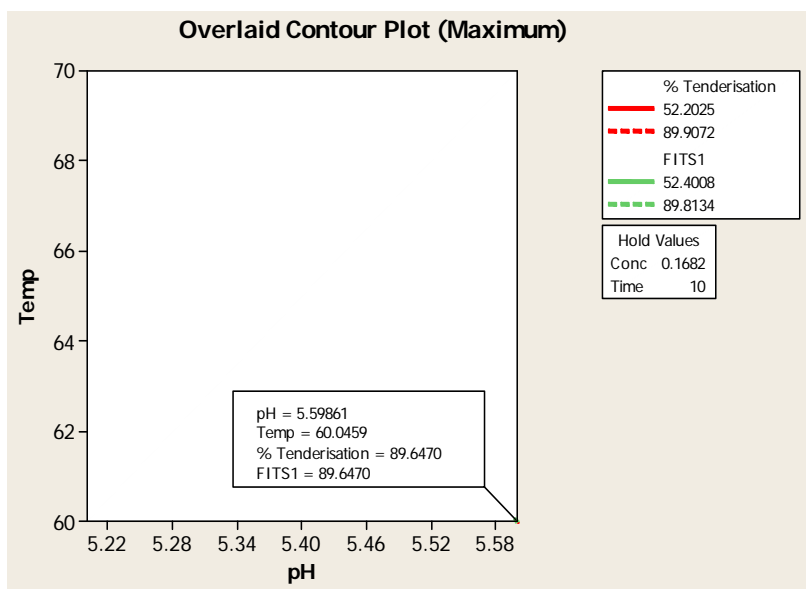

Figure 5. Overlaid contour plot at optimum condition for maximum goal; $\mathrm{pH}$ of beef of 5.6, immersion temperature of $60^{\circ} \mathrm{C}$, bromelain solution concentration of $0.1682 \%$ and immersion time of 10 minutes. 


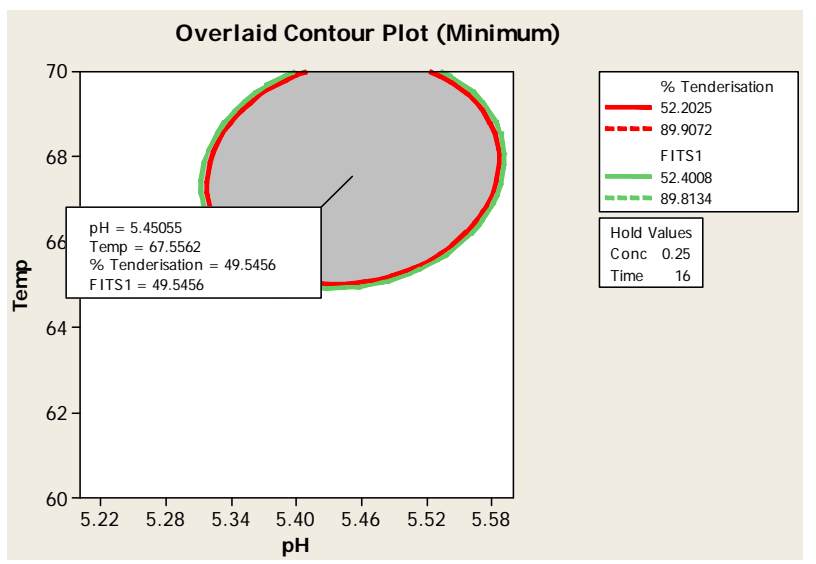

Figure 6. Overlaid contour plot at optimum condition for minimum goal; $\mathrm{pH}$ of beef of 5.45 , immersion temperature of $68^{\circ} \mathrm{C}$, bromelain solution concentration of $0.25 \%$ and immersion time of 16 minutes.

Table 6. Comparison values of target and predicted responses for different optimum conditions and feasibilities of experiment.

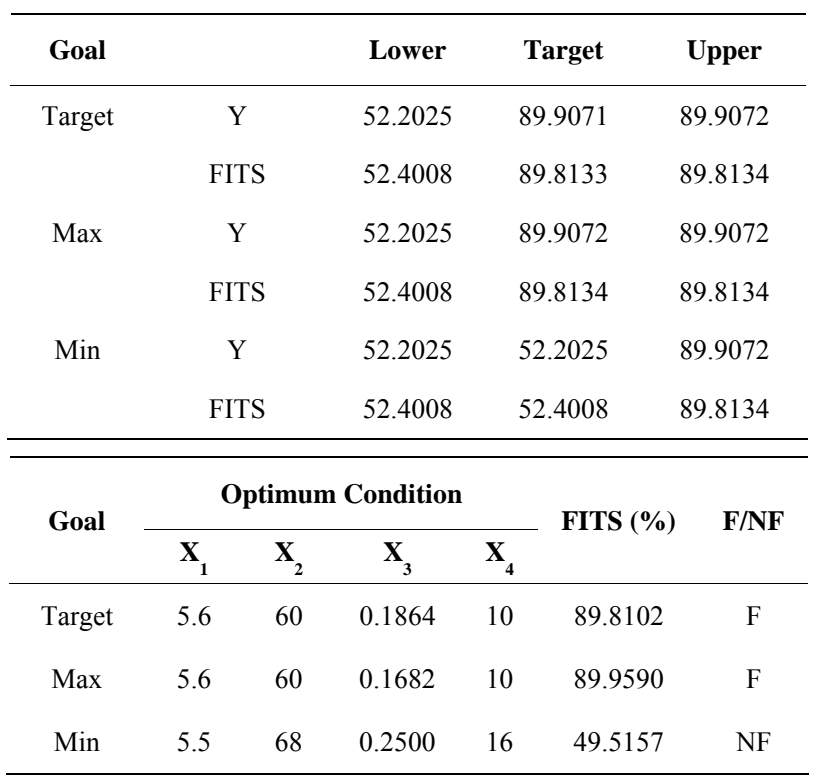

Where: $\mathrm{X}_{1}=\mathrm{pH}$ of beef, $\mathrm{X}_{2}=$ immersion temperature $\left({ }^{\circ} \mathrm{C}\right), \mathrm{X}_{3}=$ bromelain solution concentration $(\mathrm{w} / \mathrm{v} \%), \mathrm{X}_{4}=$ immersion time $(\mathrm{min}), \mathrm{Y}=$ actual response $(\%)$, FITS $=$ predicted response $(\%), F=$ feasible, NF $=$ not feasible.

immersion time of 10 minutes were feasible to be carried out. Meanwhile, optimum condition for minimum goal with $\mathrm{pH}$ of beef of 5.5 , immersion temperature of $68^{\circ} \mathrm{C}$, bromelain solution concentration of $0.25 \%$ and immersion time of 16 minutes was not feasible to be carried out. This is because according to the overlaid contour plots for target and maximum goals as shown in Figures $\mathbf{4}$ and 5, respectively, the optimum conditions of target and maximum goals located in white or feasible region. Meanwhile, the overlaid contour plot of minimum goal as shown in Figure 6 located in grey or not-feasible region. However, optimum condition from maximum goal was chosen because the target and FITS values was closer.

Contour and surface plots for beef tenderisation treated with bromelain at feasible optimum condition are shown in Figures 7 and 8, respectively.

2D contour and 3D surface plots are the graphical representatives of the regression equation illustrating the function of two factors at a time while holding other factors at a fixed level [27]. The 2D contour and 3D surface plots as demonstrated in Figures $\mathbf{7}$ and 8, respectively showed the effect of $\mathrm{pH}$ of beef, immersion temperature $\left({ }^{\circ} \mathrm{C}\right)$, bromelain solution concentration $(\%)$ and immersion time (min) on beef tenderisation. The plots illustrating the values for $\mathrm{pH}$ of beef and immersion temperature while holding the values of bromelain solution concentration and immersion time at $0.1682 \%$ and 10 minutes, respectively.

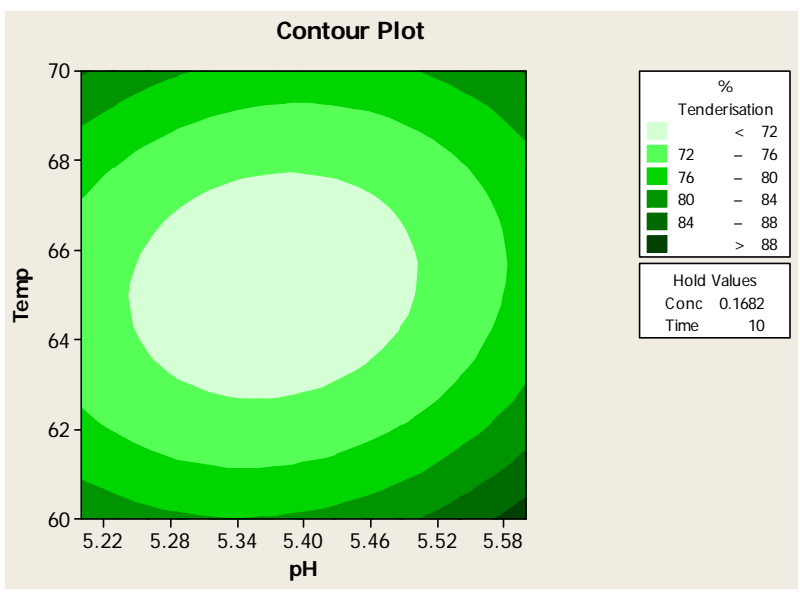

Figure 7. Contour plot of beef tenderisation treated with bromelain at feasible optimum condition; $\mathrm{pH} 5.6$, immersion temperature of $60^{\circ} \mathrm{C}$, bromelain solution concentration of $0.1682 \%$ and immersion time of 10 minutes (holding value:bromelain solution concentration and immersion time fixed at $0.1682 \%$ and 10 minutes, respectively).

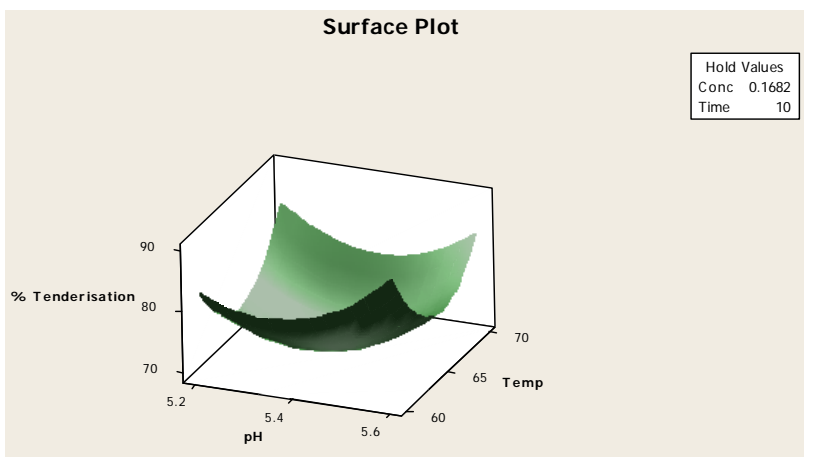

Figure 8. Surface plot of beef tenderisation treated with bromelain at feasible optimum condition; $\mathrm{pH} 5.6$, immersion temperature of $60^{\circ} \mathrm{C}$, bromelain solution concentration of $0.1682 \%$ and immersion time of 10 minutes (holding value : bromelain solution concentration and immersion time fixed at $0.1682 \%$ and 10 minutes, respectively). 
Table 7. Comparison of verification and predicted values of beef tenderisation treated with bromelain at feasible optimum condition.

\begin{tabular}{|c|c|c|c|c|c|}
\hline \multicolumn{4}{|c|}{ Optimum condition } & \multirow{2}{*}{$\begin{array}{c}\mathrm{V} \\
(\%)\end{array}$} & \multirow{2}{*}{$\begin{array}{c}\mathbf{P} \\
(\%)\end{array}$} \\
\hline $\mathbf{X 1}$ & $\mathrm{X} 2$ & $\mathrm{X} 3$ & $\mathrm{X} 4$ & & \\
\hline 5.6 & 60 & 0.1682 & 10 & 89.571 & 89.813 \\
\hline
\end{tabular}

Where: $\mathrm{X}_{1}=\mathrm{pH}$ of beef, $\mathrm{X}_{2}=$ immersion temperature $\left({ }^{\circ} \mathrm{C}\right), \mathrm{X}_{3}=$ bromelain solution concentration $(\mathrm{w} / \mathrm{v} \%), \mathrm{X}_{4}=$ immersion time $(\mathrm{min}), \mathrm{V}=$ verification value, $\mathrm{P}=$ predicted value.

Circular or elliptical shapes of contour plot indicate whether the reciprocal interactions between the factors are significant or not. Circular contour plot indicates the interactions between corresponding factors are negligible, while elliptical contour plot indicates the interactions between corresponding factors are significant [30][20]. Results of the present study showed that the contour plot was elliptical shape thus indicates significant interaction effect between $\mathrm{pH}$ of beef and immersion temperature on beef tenderisation.

The surface plot showed that the beef tenderisation increased at the lower and higher levels of $\mathrm{pH}$ of beef and immersion temperatures while at the middle level of $\mathrm{pH}$ of beef and immersion temperature, the beef tenderisation decreased.

Verification of beef tenderisation treated with bromelain at the feasible optimum condition was performed and the result is shown in Table 7.

The verification value of the beef tenderisation treated with bromelain at the feasible optimum condition was $89.571 \%$ which was very close to the predicted value with $89.813 \%$. Since the difference between the verification and predicted values was less than $5 \%$, therefore the feasible optimum condition of the beef tenderisation predicted by MINITAB Software Version 15 was acceptable.

\section{CONCLUSIONS}

The determination coefficient $\mathrm{R}^{2}(99.97 \%)$ was high, thus the experimental data was acceptable. Optimum condition for the tenderisation of beef by bromelain using RSM had been determined. It was found that beef could be optimise tenderized $89.907 \%$ at the optimum condition $\mathrm{pH}$ of beef of 5 , immersion temperature of $60^{\circ} \mathrm{C}$, bromelain solution concentration of $0.1682 \%$ and immersion time of 10 minutes. It aws also found that the difference between the verification and predicted values was less than $5 \%$, therefore, the optimum condition for the beef tenderisation predicted by MINITAB Software Version 15 could be accepted.

\section{ACKNOWLEDGEMENTS}

Special thanks to Ministry of Higher Education, Malaysia for fund- ing this project under Fundamental Research Grant Scheme [600RMI/ST/FRGS/Fst(32/2010)] and also Peninsula Plantation Sdn Bhd, Simpang Renggam, Johor, Malaysia for supplying pineapple for this project.

\section{REFERENCES}

[1] Maiti, A.K., Ahlawat, S.S., Sharma, D.P. and Khanna, N. (2008) Application of natural tenderisers in meat - A review. Agricultural Reviews, 29(3), 226-230.

[2] Deatherage, F.E.(1974) New approaches to the marketing of red meats. New protein food, Academic Press, New York. doi:10.1016/B978-0-12-054801-9.50012-0

[3] Żochowska-Kujawska, J., Lachowics, K. and Sobczak, M. (2010). The tenderisation of wild boar meat using a calcium chloride, kefir, wine and pineapple marinade. Electronic Journal of Polish Agricultural Universities, 13, $1-8$.

[4] Umesh Hebbar, H., Sumana, B. and Raghavarao, K.S.M. S.(2008) Use of reverse micellar systems for the extraction and purification of bromelain from pineapple wastes. Bioresource Technology, 99, 4896-4902. doi: 10.1016/j.biortech.2007.09.038

[5] Hale, L.P., Greer, P.K., Trinh, C.T. and James, C.L. (2005) Proteinase activity and stability of natural brome- lain preparations. International Immunopharmacology, 5(4), 783-793. doi: 10.1016/j.intimp.2004.12.007

[6] Ngampanya, B. and Phongtongpasuk, S. ( 2006) Effects of sucrose concentration on crude bromelain production of in vitro culture of pineapple (Ananas comosus var. 'Pattavia'). Kasetsart Journal Natural Science, 40, 129 -134 .

[7] Devakate, R.V., Patil, V.V., Waje, S.S. and Thorat, B.N. (2009) Purification and drying of bromelain. Separation and Purification Technology, 64, 259-264. doi: 10.1016/j.seppur.2008.09.012

[8] Ke, S., Huang, Y., Decker, E.A. and Hultin, H.O. (2009). Impact of citric acid on the tenderness, microstructure and oxidative stability of beef muscle. Meat Science, 82(1), 113-118. doi: 10.1016/j.meatsci.2008.12.010

[9] Jerez, N.C., Calkins, C.R. and Velazco, J. (2003) Prerigor injection using glycolytic inhibitors in low-quality beef muscles. Journal of Animal Science, 81, 997- 1003.

[10] Ketnawa, S., Sai-Ut, S., Theppakorn, T., Chaiwut, P. and Rawdkuen, S. (2009) Partitioning of bromelain from pineapple peel (Nang Lae cultv.) by aqueous two phase system. Asian Journal of Food and Agro-Industry, 2, 457-468.

[11] Ketnawa, S., Chaiwut, P. and Rawdkuen, S. (2011) Aqueous two-phase extraction of bromelain from pineapple peels ('Phu Lae' cultv.) and its biochemical properties. Food Science and Biotechnology, 20, 1219-1226.

[12] Tripathi, A. and Srivastava, S.K. (2012) Biodegradation of orange $\mathrm{G}$ by a novel isolated bacterial strain Bacillus megaterium ITBHU01 using Response Surface Methodology. African Journal of Biotechnology, 11, 1768- 1781.

[13] Jeong, G.T., Yang, H.S. and Park, D.H. (2009) Optimisa- 
tion of transesterification of animal fat ester. Bioresource Technology, 100(1), 25-30.

[14] Sharma, S., Malik, A. and Satya, S. (2009) Application of response surface methodology (RSM) for optimisation of nutrient supplementation for $\mathrm{Cr}$ (V1) removal by As- pergillus lentulus AML05. Journal of Hazardous Materi-als, 164, 1198-1204.

[15] Cepeda, E.A. and Calvo, B. (2008) Sunflower oil hydrogenation: Study using response surface methodology. Journal of Food Engineering, 89(4), 370-374. doi: 10.1016/j.jfoodeng.2008.01.012

[16] Siti Mazlina, M.K., Abdul Ghani, L.A., Nur 'Aliaa, A.R., Siti Aslina, H. and Rozita, O. (2008) Comparison on optimisation of star fruit juice using RSM between two Malaysian star fruit varieties (B11 and B10). Pertanika Journal of Science and Technology, 16, 1-13.

[17] Kongkaew, A., Usansa, U. and Wanapu, C. (2012) Optimisation of wort production from rice malt using enzymes and barley malt. African Journal of Biotechnology, 11, 9941-9949.

[18] Mullai, P.N., Syed Ali F. and Eldon R.R. (2010) Statistical analysis of main and interaction effects to optimize xylanase production under submerged cultivation conditions. Journal of Agricultural Science, 2, 144-153.

[19] Thanapimmetha, A., Vuttibunchon, K., Saisriyoot, M. and Srinophakun, P. (2011) Chemical and microbial hydrolysis of sweet sorghum bagasse for ethanol production. World Renewable Energy Congress-Sweden, Linköping, Sweden. 8-13 May 2011, 1, 389-396.

[20] Rengadurai, S., Preetha, B. and Viruthagiri, T. (2012) Response surface technique for optimisation of parameters for decolorization of Reactive red BS using Trametes hiruta. International Journal of ChemTech Research, 4, 21-28.

[21] Sudamalla, P., Saravanan, P. and Matheswaran, M. (2012) Optimisation of operating parameters using response surface methodology for adsorption of crystal violet by activated carbon prepared from mango kernel. Sustainable Environment Research, 22, 1-7.

[22] Sudamalla, P., Saravanan, P. and Matheswaran, M. (2012) Optimisation of operating parameters using response surface methodology for adsorption of crystal violet by activated carbon prepared from mango kernel. Sustainable Environment Research, 22, 1-7.
[23] Fang, X.L., Feng, J.T., Zhang, W.G., Wang, Y.H. and Zhang, X. (2010) Optimization of growth medium and fermentation conditions for improved antibiotic activity of Xenorhabdus nematophila TB using a statistical approach. African Journal of Biotechnology, 9, 8068-8077. doi: 10.5897/ajb09.1939

[24] Hismath, I., Wan Aida, W.M. and Ho, C.W. (2011) Optimisation of extraction conditions for phenolic compounds from neem (Azadirachta indica) leaves. International Food Research Journal, 18, 931-939.

[25] Prakash. O, Talat, M., Hasan, S.H. and Pandey, R.K. (2008) Factorial design for the optimisation of enzymatic detection of cadmium in aqueous solution using immobilised urease from vegetable waste. Bioresource Technology, 99, 7565-7572.

[26] Panwal, J.H., Viruthagiri, T. and Baskar, G. (2011) Statistical modeling and optimization of enzymatic milk fat splitting by soybean lecithin using response surface methodology. International Journal of Nutrition and Metabolism, 3, 50-57.

[27] Datta, D. and Kumar, S. (2012) Modeling and optimisation of recovery process of glycolic acid using reactive extraction. International Journal of Chemical Engineering and Applications, 3, 141-146. doi: 10.7763/ijcea.2012.v3.175

[28] Patel, S., Kothari, D. and Goyal, A. (2011) Enhancement of dextransucrase activity of Pediococcus pentosaceus SPAm1 by Response Surface Methodology. Indian Journal of Biotechnology, 10, 346-351.

[29] Noordin, M.Y., Venkatesh, V.C., Sharif, S., Elting, S. and Abdullah, A. (2004) Application of response surface methodology in describing the performance of coated carbide tools when turning AISI 1045 steel. Journal of Materials Processing Technology, 145, 46-58. doi: 10.1016/s0924-0136(03)00861-6

[30] Trinh, T.K. and Kang, L.S. (2010) Application of response surface method as an experimental design to optimise coagulation tests. Environmental Engineering Research, 15, 63-70. doi: 10.4491/eer.2010.15.2.063

[31] Yu, S.-J., Zhang, Y., Li, C.-R., Zhang, Q., Ma, Z.-Y. and Fan, M.-Z. Optimisation of ultrasonic extraction of mycelia polysaccharides from Paecilomyces hepiali using response surface methodology and its antioxidant activity. African Journal of Biotechnology, 10, 17241-17250. 